\title{
APPLICATION OF LEAF FERTILIZER AND PLANT HORMONES TO ACCELERATE SHOOT CUTTINGS GROWTH ON THE POTATO VARIETIES OF GRANOLA LEMBANG (Solanum tuberosum L.)
}

Erny Ishartati $\left.{ }^{1 *}\right)$, Rehan Prasetya ${ }^{2}$

Agrotechnology Department, Faculty of Agriculture and Animal Science, University of Muhammadiyah Malang, Malang, 65144, Indonesia

*) Email: ishartati.erny@gmail.com

\begin{abstract}
An important factor in the productivity of potatoes is the procurement of quality potato seeds. Procurement of potato seeds can be done several ways, one of which is by cuttings. Giving plant hormones in cuttings can encourage and accelerate the formation of roots, stimulate the formation of new shoots, and increase the number and quality of shoots and roots. This study uses a split-plot design factorial with the first factor is the influence of various kinds of leaf fertilizer consisting of 3 levels, namely PAB (AB Mix), PGD (Gandasil D) and PG (Growmore), and the second factor is some natural plant hormones which consist of Z0 (Rootone F / control), Z1 (bamboo shoots), Z2 (coconut water), Z3 (aloe vera) and Z4 (shallots). All treatments were repeated 3 times. The data obtained were analyzed using orthogonal contrast for treatment vs. control testing. F test to determine diversity, if there is a diversity of treatment followed by BNJ test level of 5\%. Observation variables included: when the roots appeared, plant height, number of leaves, and stem diameter. The results showed that there was no interaction between the administration of leaf fertilizer with extracts of some plant hormones, only that the treatment of the leaves of the gandasil D fertilizer had a very significant effect on plant height parameters, with an average of $6.57 \mathrm{~cm}$. whereas in orthogonal analysis the contrast between control and treatment, control tends to be higher in value.
\end{abstract}

Keywords: Potato cuttings, Leaffertilizer, Plant hormones

\section{INTRODUCTION}

Potato plant (Solanum tuberosum L.) is a commodity that gets top priority, this is because the potato plant has the potential to be developed as a source of carbohydrates. This crop is included as the fourth major food crop in the world, after rice, wheat and corn (Asgar, 2013).

Procurement of quality seeds is needed to overcome the problems that often occur. Procurement of potato seeds can be done several ways, one of which is by cuttings. Cuttings are the procurement of seeds that can be said to be simple. The success of plant growth by means of cuttings is characterized by the formation of roots in plant parts that have been cut and planted into the planting medium. Hormones in the body of the plant are very few in number, so we need hormones from outside, namely growth regulators to accelerate and increase root formation (Parnata, 2010).

In addition to giving growth around, providing nutrients is also very important to 
increase maximum productivity results. Giving nutrients in addition to being given by soil is generally given through leaves. Leaf fertilizer is the ingredients or elements that are given through the leaves by spraying or watering the leaves of the plant so that it can be directly absorbed to meet the needs for growth and development, it is in agreement with, Desiana, et al., (2013) to meet the nutrient requirements for plants is done by applying fertilizer to the media so that healthy plant seedling growth can be achieved. According to Priangga, et al., (2013) the use of liquid organic fertilizer provides benefits, this fertilizer can be used by splashing or spraying directly on plants and the results will be more evenly distributed, this is due to liquid organic fertilizer $100 \%$ soluble.

This study aims to determine the response of leaf fertilizer and plant hormones give effect to the growth of shoots of potato buds (Solanum tuberosum L.) Granola lembang cultivars.

\section{METHOD}

This study uses a factorial split-plot design which is repeated 3 times. The first factor is placed as the main plot, the influence of the type of leaf fertilizer consists of 3 levels, that is $P A B=A B$ Mix, PGD = Gandasil D and PG = Growmore. The second factor is placed as sub-plots (combination of natural plant extracts) consisting of Z0 = Rooten F (control), Z1 = Bamb So that a combination of 15 plants was obtained and each treatment combination was repeated 3 times to obtain 45 experimental units and each experimental unit consisted of 8 plant populations with 3 samples in it so that the total was 360 plants.00 shoots, Z2 = Coconut water, Z3 = Aloe vera and $Z 4=$ shallot. And obtained such a combination is :

PAB Z0 = Fertilizer AB Mix + Rootone F PAB Z1 = Fertilizer AB Mix + bamboo shoots $\mathrm{PAB} Z 2$ = Fertilizer $\mathrm{AB}$ Mix + coconut water $\mathrm{PAB} Z 3=$ Fertilizer $\mathrm{AB}$ Mix + aloe vera PAB Z4 = Fertilizer AB Mix + onion PGD Z0 = Fertilizer Gandasil D + Rootone F PGD Z1 = Fertilizer Gandasil D + bamboo shoots

PGD Z2 = Fertilizer Gandasil D + coconut water

PGD Z3 = Fertilizer Gandasil D + aloe vera

PGD Z4 = Fertilizer Gandasil D + shallot

$P G$ Z0 = Growmore Fertilizer + Rootone F

$P G Z 1$ = Growmore fertilizer + bamboo shoots

PG Z2 = Growmore fertilizer + coconut water $P G Z 3$ = Growmore + aloe vera fertilizer

PG Z4 = Growmore Fertilizer + shallots

Variables observed in this study were published: when roots appeared, plant height, number of leaves and stem diameter appeared. The observational data were 
analyzed using the $\mathrm{F}$ test at $5 \%$ level if there was a real influence between treatments further testing was done using a BNJ level of 5\%. Also performed Contrast Orthogonal Test to determine the difference between treatment and control.

\section{RESULT AND DISCUSSION}

\section{Root Appears}

Based on the results of an analysis of the variety when the roots appear, showed no real difference between some plant extracts. The mean value when a plant extract appears some plant extracts.

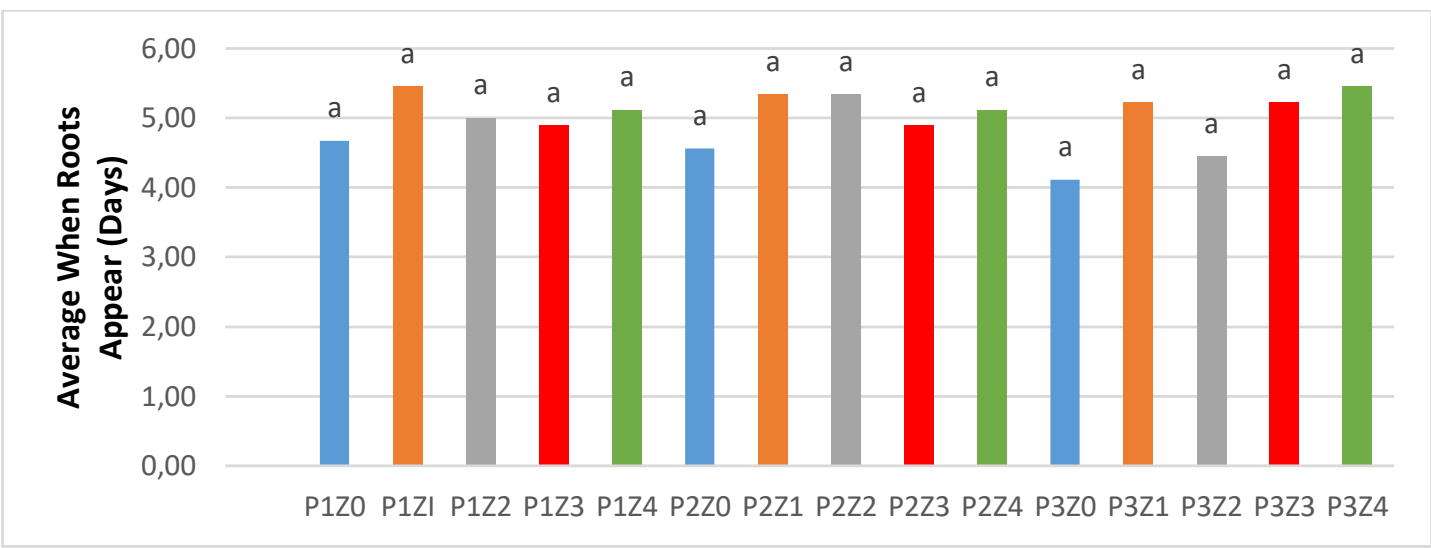

Figure 1. When the mean appears with a combination of several plant extracts on potato cuttings.

Information :

- The mean value accompanied by the same letters between treatment combinations shows no significant difference according to the BNJ test level of $5 \%$.

- Z0 (Rootone f), Z1 (Bamboo shoots), Z2 (Coconut water), Z3 (Aloe vera) and Z4 (Shallots).

Figure 1. shows that the average root emergence did not show a non-significant effect between the treatment of leaf fertilizer and plant extract but the root appeared most quickly in the P3ZO treatment (growmore + rootone f).

\section{Plant Height}

Based on the analysis of various types of height increase of potato plants showed no significant interaction between the treatment of some plant extracts and the treatment of leaf fertilizers. Separately at 14 DAP the treatment of fertilizers had a very significant effect with the highest average height of plants on the Gandasil D treatment with an average value of $6.57 \mathrm{~cm}$ (Appendix $2)$. The mean value of plant growth in the treatment of some plant extracts and leaf fertilizer treatments in figures 2, 3 and 4. 


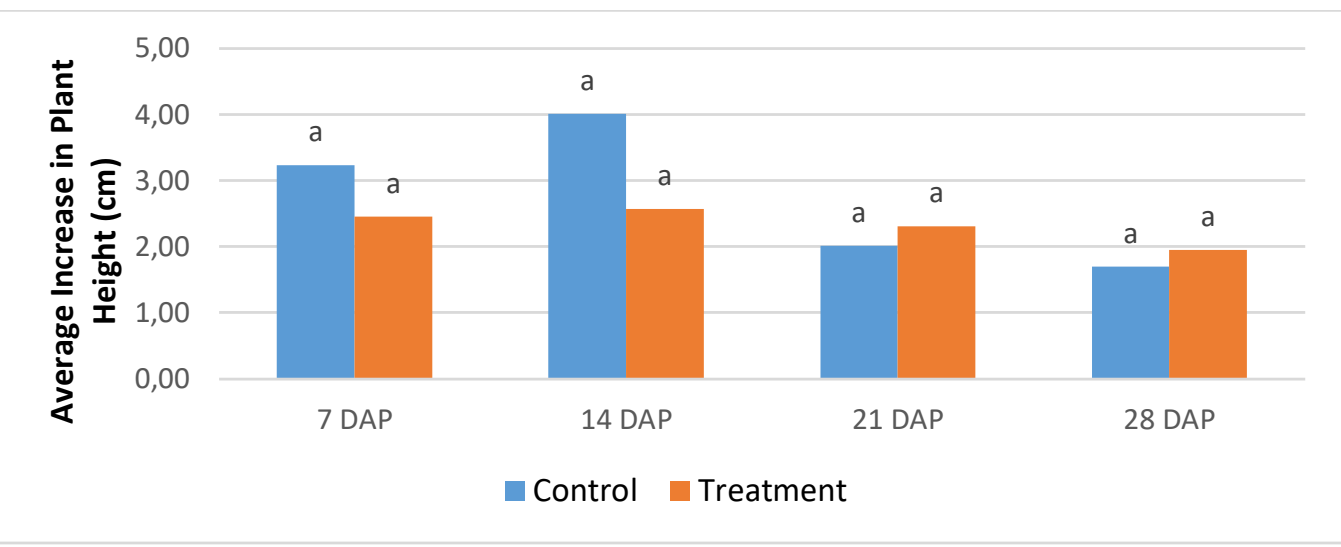

Figure 2. Average height increase of plants aged 7-28 DAP on potato bud cuttings.

Information :

- The mean value accompanied by the same letter at the same age shows no significant difference according to the BNJ test level of $5 \%$.

Figure 3. shows that the mean the higher mean height was found in the increase in plant height was not significantly control compared to the treatment. different from age $7,14,21$, and 28 DAP, but

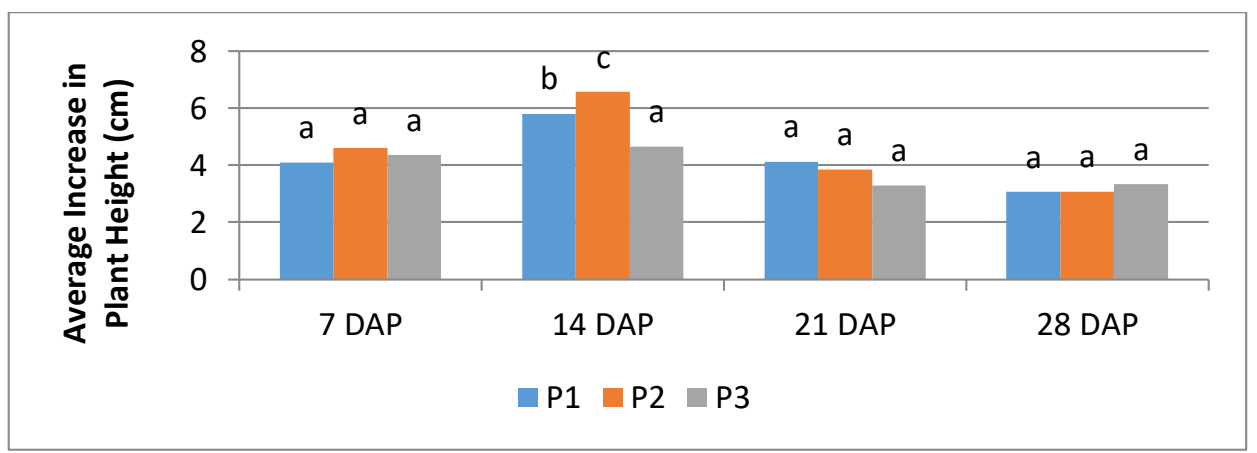

Figure 3. The increased average height of potato plants at the age of 7-28 DAP with the treatment of leaf fertilizer on potato cuttings.

Information :

- The average value accompanied by the same letter at the same age shows no significant difference based on the BNJ test at $5 \%$ level.

- P1 (AB Mix fertilizer), P2 (Gandasil D fertilizer), P3 (Growmore).

In Figure 3. shows the average height increase of potato plants at the age of 14 DAP has a very significant effect with the highest value of 6.57 in P2 (Gandasil D) treatment. 


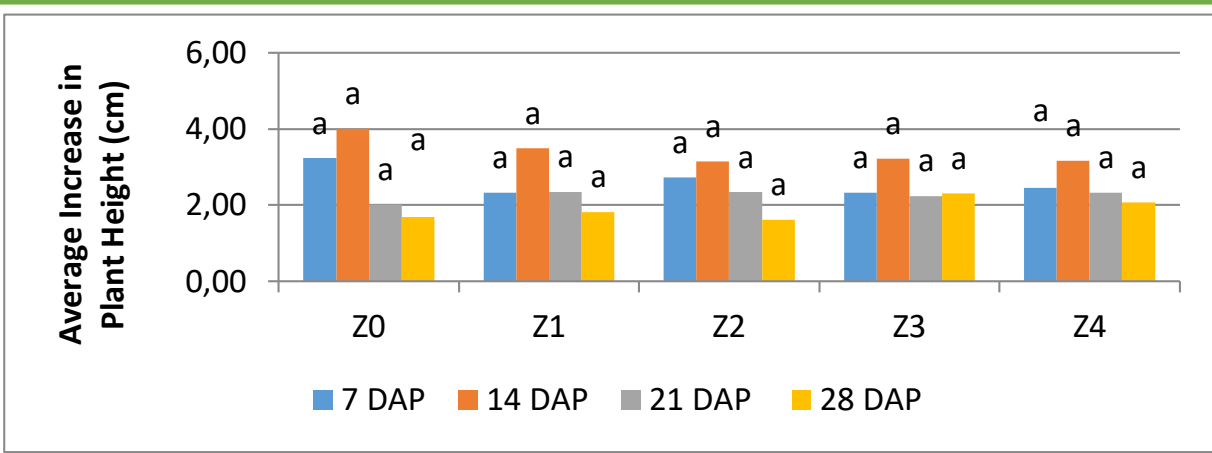

Figure 4. Increased height of potato plants at the age of 7-28 DAP with the treatment of some plant extracts on potato cuttings.

Information :

- The average value accompanied by the same letter at the same age shows no significant difference based on the BNJ test at $5 \%$ level.

Figure 4. shows that the mean interactions showed no significant difference increase in plant height showed no significant effect at age 7, 14, 21 and 28 DAP, but the treatment was higher in the Z0 (control) treatment than in Z1, Z2, Z3 and Z5 treatments.

\section{Number Of Leaves} between the treatment of some plant extract hormones and the treatment of leaf fertilizers. The mean value of increasing the number of leaves of several plant extracts and leaf fertilizer treatments is presented in figures 5,6 and 7 .

Based on the analysis of the variance in the number of leaves, the number of

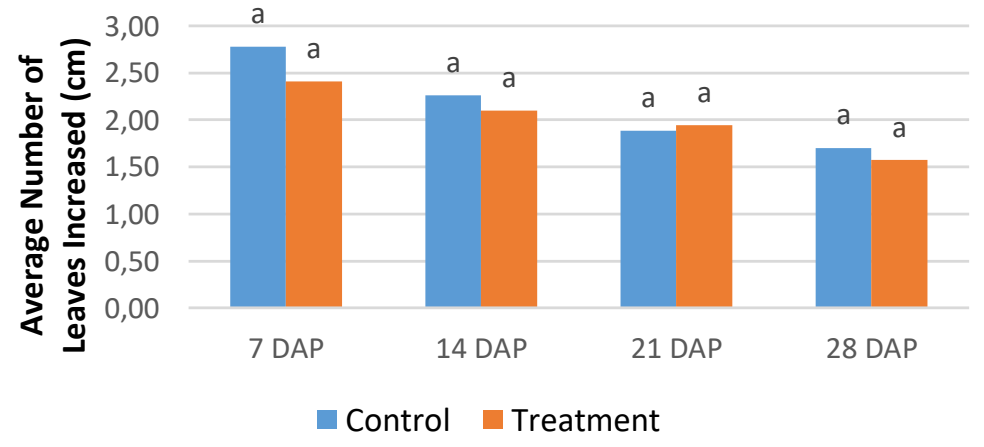

Figure 5. Average increase in the number of leaves aged 7-28 DAP on potato bud cuttings. Information :

- The mean value accompanied by the same letter at the same age shows no significant difference according to the BNJ test level of $5 \%$. 
Figure 5. shows that the average and 28 DAP, but the higher is in the control increase in the number of leaves shows no compared to the treatment of potato cuttings. significant effect from the age of $7,14,21$,

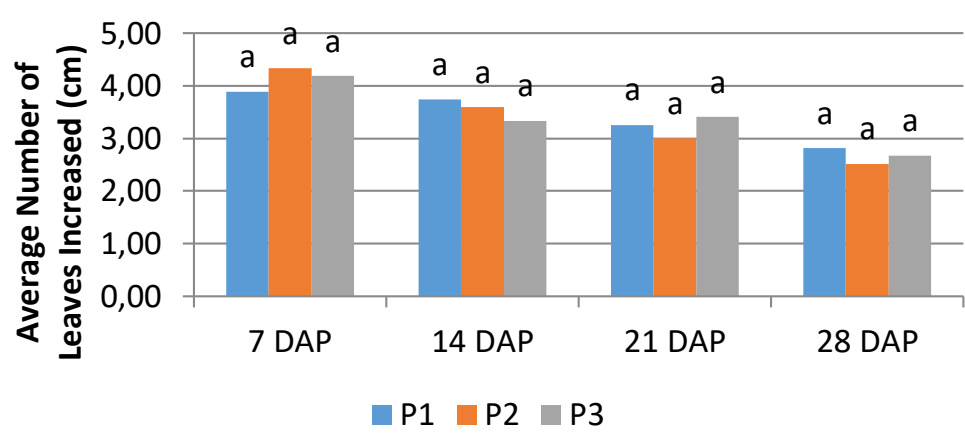

Figure 6. Increase in the average number of potato leaves at the age of 7-28 DAP in the treatment of leaf fertilizer on potato cuttings.

Information :

- The average value accompanied by the same letter at the same age shows no significant difference based on the BNJ test at $5 \%$ level.

- P1 (AB Mix fertilizer), P2 (Gandasil D fertilizer), P3 (Growmore).

In Figure 6 shows that the average of 7 DAP to 28 DAP is higher at the age of 7 increase in the number of leaves at the age DAP treatment P2 (dandulated fertilizer D).

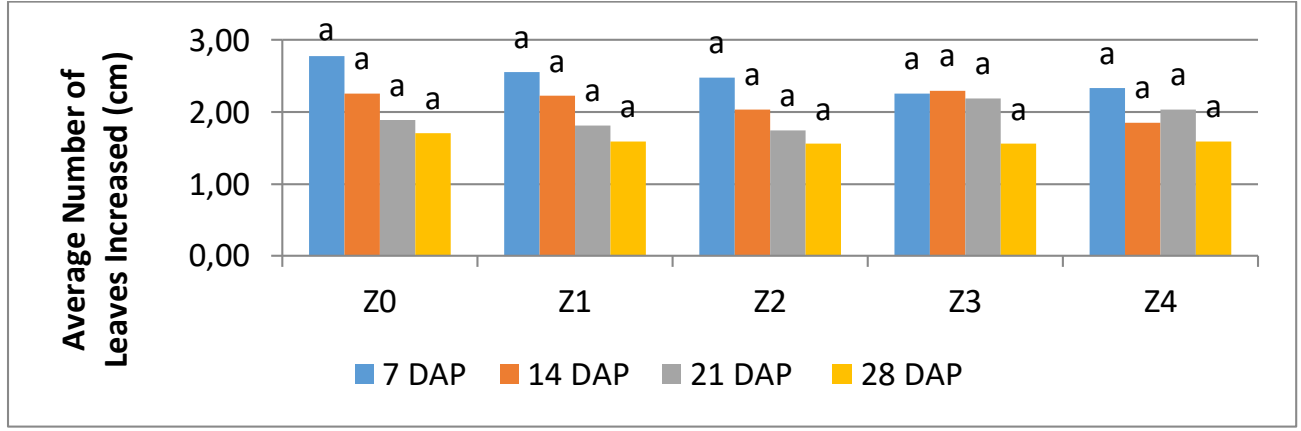

Figure 7. Increasing the number of leaves of potato plants at the age of 7-28 DAP treatment of plant extracts on potato cuttings.

Information :

- The average value accompanied by the same letter at the same age shows no significant difference based on the BNJ test at $5 \%$ level.

- Z0 (Rootone f), Z1 (Bamboo shoots), Z2 (Coconut water), Z3 (Aloe vera) and Z4 (Shallots).

Figure 7 shows that the average increase in the number of leaves at the age of 7 DAP is higher than 14,21 and 28 DAP but it has no significant effect on the treatment of some plant extracts. 


\section{Diameter Of Stem}

Based on the analysis of the variance in the number of leaves, there was no significant interaction between the treatment of some plant extracts and the treatment of leaf fertilizer (appendix 4). The mean value of increasing the number of leaves of several plant extracts and leaf fertilizer treatments is presented in figures 8,9 and 10 .

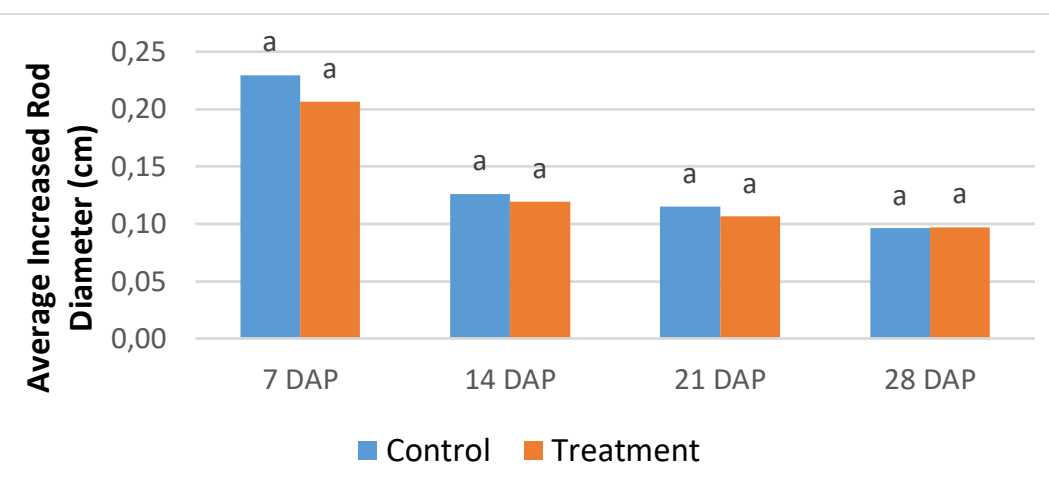

Figure 8. Average increase in stem diameter at the age of 7-28 DAP on potato cuttings. Information :

- The mean value accompanied by the same letter at the same age shows no significant difference according to the BNJ test level of $5 \%$.

Figure 8 shows that the mean but that there was a higher control than the increase in stem diameter had no significant treatment of potato cuttings. effect from the age of $7,14,21$ and 28 DAP,

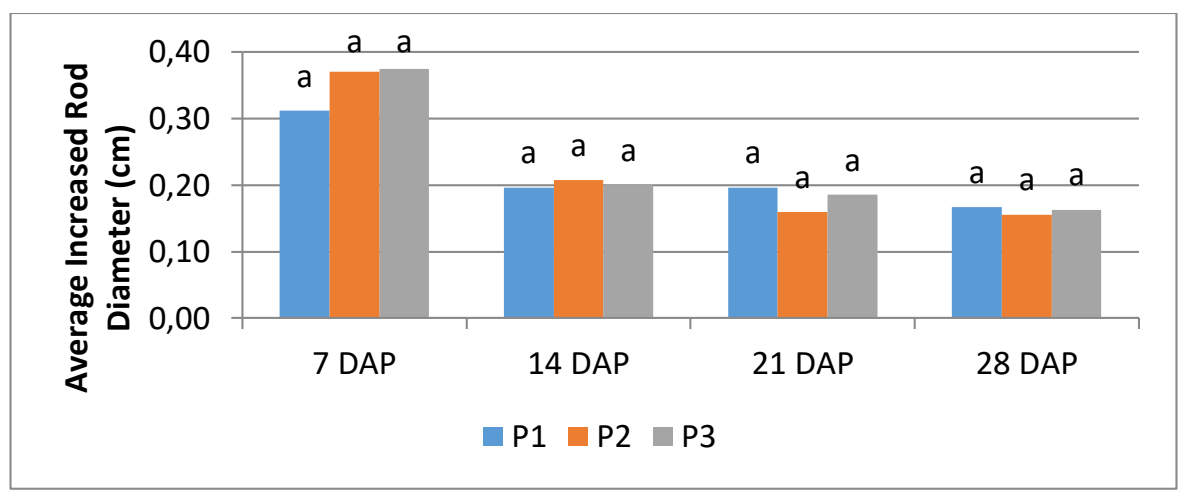

Figure 9. Increased mean diameter of potato stems at the age of 7-28 DAP treatment of leaf fertilizer on potato cuttings.

Information :

- The average value accompanied by the same letter at the same age shows no significant difference based on the BNJ test at $5 \%$ level.

- P1 (AB Mix fertilizer), P2 (Gandasil D fertilizer), P3 (Growmore). 
In Figure 9 shows that the average increase in the diameter of the stem age 7
DAP to 28 DAP is higher at the age of 7 DAP P3 (Growmore) treatment.

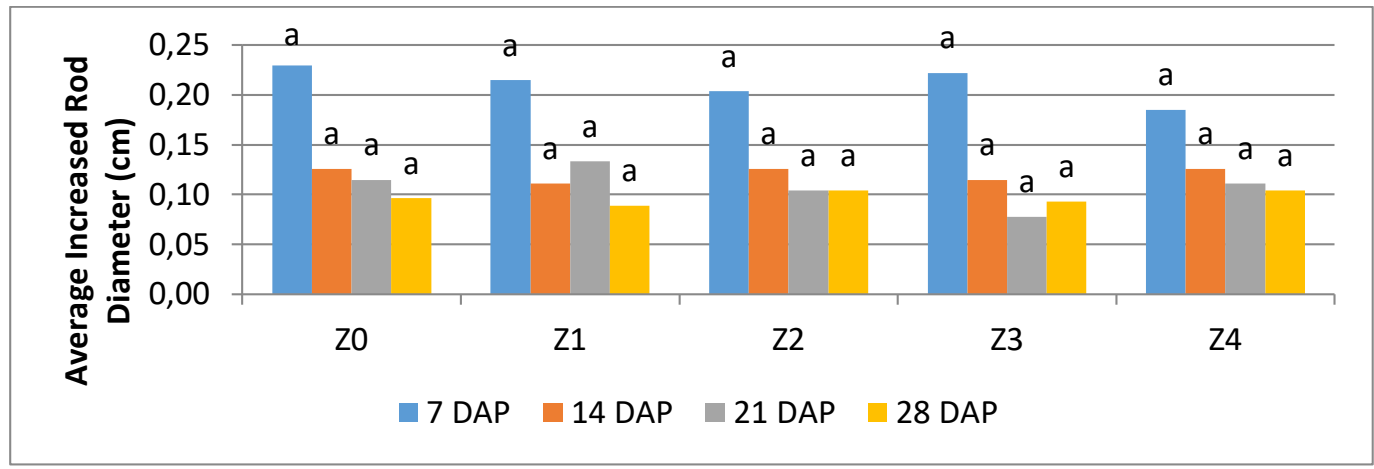

Figure 10. Average increase in diameter of potato stems at the age of 7-28 DAP treatment of plant extracts on potato cuttings.

Information :

- The average value accompanied by the same letter at the same age shows no significant difference based on the BNJ test at $5 \%$ level.

- Z0 (Rootone f), Z1 (Bamboo shoots), Z2 (Coconut water), Z3 (Aloe vera) and Z4 (Shallots).

Figure 10. shows that the average increase in stem diameter at 7 DAP was higher than those at 14, 21 and 28 DAP but did not significantly affect the treatment of some plant extracts.

Based on the results of the analysis of variance, it was obtained when the roots appeared most quickly at P3Z0 (control) which was an average of 4 days compared to extracts of several plants. Use of growth around to stimulate root formation on cuttings. Growth around Rootone $F$ is included in the Auksin synthesis which is very active in the Experiment and reproduces out of the roots, uptake of air, will not be much and can compensate for the evaporation of air in the soil. Auxin has a role in plant growth, which can stimulate the growth of roots in cuttings. In addition, the formation of roots is influenced by the composition of the appropriate hormones so that root growth is not inhibited (Marpaung, 2015). Factors that determine the success of cuttings to take root are the selection and management of planting media. Plants that are propagated by means of seeding must be grown on planting media that can support the formation of roots and shoots so that new plants are identified that are identical to the parent (Flaishman et al., 2008).

Based on the figure 4 the average increase in height of potato plants is higher 
in the application of Gandasil D fertilizer with a value of $6.57 \mathrm{~cm}$ at the age of 14 DAP, in the application of $A B$ Mix fertilizer with a value of 5.80 , while in the application of Growmore fertilizer with a value of 4.65 . This is because fertilizer contains PPN nutrients needed by plants, so that plants can be easily utilized in metabolism which has an impact on increasing growth in this case plant height (Hakim, 2006)

According to Palemba (2012), the application of Gandasil D leaf fertilizers gave significantly different results on the growth of red A. cadamba seeds. Whereas in the treatment of extracts some of the best plants are the use of a regulating agent Rooton $F$ at 14 DAP. This is because Rootone F contains a more varied auxin content (NAA and IBA) compared to the auxin content in extracts of several plants, so getting a better plant height results. This is supported by a statement from Mulyono (2010), one of the functions of auxin can extend plant cells by affecting cell wall metabolism that results in rising plant height walls.

Based on the results of the analysis of the average increase in the number of leaves, showed that the administration of leaf fertilizer and the treatment of several plant extract hormones had no significant effect starting at 7 DAP up to 28 DAP. It is suspected that the plants do not get fertilizer with the right concentration, according to Rizqiani et al,.(2006), plant growth and development will be good if the nutrients supplied with the right dose, because the application of fertilizers with inappropriate concentrations will affect the crop yield. On the average increase in the number of leaves given some natural plant extracts showed no significant effect. This is due to lack of sufficient concentration in the administration of extracts of growth regulators. In accordance with the opinion of Trisna et al., (2013), that plants can grow well if the availability of plant growth regulators is sufficient to encourage plant growth, especially in the process of leaf formation. The increase in the number of leaves is caused by the administration of plant extracts that have contents according to Arif et al., (2016), exogenous growt stimulants in cooperation with endogenous growth around in cuttings. The auxin hormone contained in all treatments is a growth regulator which can play a role in stimulating the growth of young tissues such as leaves. In the study of Vernoux et al. (2011) showed that the response of auxin administration is very complex, depending on the level of auxin administration.

Based on the results of the analysis of variance on the application of leaf fertilizer 
did not significantly affect the average increase in diameter of the potato stems, but the highest observation at 7 DAP where the Growmore fertilizer is higher value of $0.37 \mathrm{~cm}$ compared to other fertilizer treatments. According to Nuryani (2007), if sufficient nitrogen supply, plant leaves will grow larger and expand the surface available for photosynthesis so that the rate of photosynthesis that increases will produce photosynthates in large quantities. The photosynthate is then used to increase the rate of growth and development of plants through the process of cell division, cell enlargement, and cell differentiation so as to increase the diameter of the stem. Whereas the treatment of some plant extracts also had no significant effect on the stem diameter of potato plants, according to Beemnet., Et al., (2011), environmental conditions and physiological status would influence the process of plant growth. However, the best extract in the treatment of shallot extract. According to Marfirani (2014), onion tubers contain the hormones auxin and giberellin, which can stimulate the growth of cuttings. The results of Siswanto et al., (2010) research, the provision of auxin as a growth regulator can increase the percentage of cuttings that form roots, accelerate root initiation, and homogenize root cuttings, so that it will affect the widening of the cell wall which will then be continued to increase the diameter of the plant stem.

\section{CONCLUSION}

Based on the results of the study can be concluded as follows,

1. There is no real interaction between the types of leaf fertilizer and natural plant extracts on the growth of potato shoot cuttings (Solanum tuberosum L.) Granola Lembang cultivars.

2. The treatment of leaf fertilizer application shows very significant effect, with the treatment of fertilizer application Gandasil D has a high average value on the observation variable plant height increase.

3. The treatment of giving natural plant extracts does not significantly affect the variables when the roots appear, plant height, number of leaves and stem diameter.

4. The Rootone F control treatment showed that the roots appeared faster, the stem diameter was greater, and the number of leaves increased faster at all age observations compared to the hormone treatment of bamboo shoots, coconut water, aloe vera and onion. 


\section{REFERENCES}

Arif M., Murniati, and Ardian. 2016. Test Some Natural Growth Regulatory Substances Against Rubber Seedling Growth (Hevea brasiliensis Muell Arg) Sleeping Eye Stum. Jom Faperta Vol 3 No. 1 February 2016.

Asgar, A. 2013. Potato Bulbs (Solonum tuberesum L.) Clones 395195.7 and CIP 394613.32 planted on the Medium Plains have Hope for Chips. Vegetable Crops Research Institute, Bandung.

Beemnet. M.K, Aster K., Solomon A.M. (2011) Effect of node number, part used and season of propagation on nursery establishment of lemon verbena (Alloysia triphyllia $\mathrm{L}$ ). In: Improving Quality Production of Horticultural Crops for Sustainable Development

Proceedings, February 4-5, 2010. Jimma University College of Agriculture and Veterinary Medicine, Jimma, Ethiopia, $30 \mathrm{pp}$ in press.

Desiana C., Banuwa I S., Evizal R., and Yusnaini S. (2013). Effect of Organic Liquid Cow Manure and Tofu Waste on the Growth of Cocoa Seedlings (Theobroma cacao L.). Faculty of Agriculture, University of Lampung.

Flaishman, M., V. Rodov, and E. Stover. 2008. The Fig: Botany, Horticulture, and Breeding. Horticultural Reviews. Volume 34 ISBN 9780470171530. John Wiley \& Sons, Inc. USA.
Hakim N. 2006. Processing of Soil Fertility with Integrated Liming Technology. Andalas University Press. Padang.

Hakim N. 2006. Processing of Soil Fertility with Integrated Calcification Technology. Andalas University Press. Padang.

Marfirani, M. 2014. Effect of giving various concentrations of onion tuber and rootone $\mathrm{f}$ filtrate on the growth of "Rato Ebu" jasmine cuttings. Lantern Bio 3 (1): 73-76.

Marpaung, and Hutabarat, 2015. Response of Growth Stimulant Types Made from Natural and Origin of Stem Cuttings on the Growth of Tin Seeds (Ficus carica L.). J. Hort. Vol. 25 No. 1, 2015.

Mulyono, D. 2010. The Effect of Auxin Growth Regulatory Substances: Indole Butiric Acid (Iba) and Cytokinins: Benzyl Amino Purine (Bap) and Kinetin in Elongation of Agarwood Cultivation (Aquilaria beccariana). Agricultural Production Technology CenterBPPT.

Nuryani, S. 2007. Effect of PPN Fertilizer on Growth and Flowering of Water Jasmine (Echinodorus paleafolius). (Thesis). University of Lampung. Bandar Lampung. 80 p.

Palemba Telji Y, Lasut. M.T, Kalangi. J.I, and Thomas. A.2012. Application of Gandasil D Leaf Fertilizer on the Growth of Jabon Merah Seedlings (Anthocephalus macrophyllus Havil). Journal entry. Forestry Science Study Program, Faculty of Agriculture, Sam Ratulangi University. 
Parnata, U.S. 2013. Increasing Harvest Results with Organic Fertilizers. Agromedia Reader. Jakarta.

Priangga R., Suwarno and Hidayat N. (2013). Effect of Liquid Organic Fertilizer Levels on Production of Dry Materials and Balance of the Fourth Defoliation of Elephant Grass Stems. Faculty of Animal Husbandry, Jenderal Soedirman University, Purwokerto.

Rizqiani. Nur Fitri, Erlina Ambarwati, and Nasih Widya Yuwono. 2006. Effect of Dose and Frequency of Liquid Organic Fertilizer on Growth and Yield of Beans (Phaseolus vulgaris L.) Lowlands, Journal of Soil and Environmental Science Vol. 7 No. 1, 43-53.

Trisna, N., H. Umar and Irmasari. 2013. The Effect of Various Types of Growth Regulatory Substances on the Growth of Teak Stump (Tectona grandis L.F). Journal of the Jungle News. 1 (1): 1-9.

Vernoux. Tera, Brunoud G., Farcot E., Morin V., Van den Daele H., Legrand J., Oliva M., Das P., Larrieu A., Wells D.. 2011. The auxin signalling network translates dynamic input into robust patterning at the shoot apex. Mol. Syst. Biol.7,508 